\title{
The last 7 millennia of vegetation and climate changes at Lago di Pergusa (central Sicily, Italy)
}

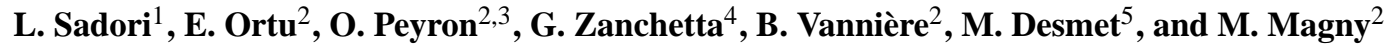 \\ ${ }^{1}$ Dipartimento di Biologia Ambientale, Università di Roma "La Sapienza", Piazzale Aldo Moro 5, 00185 Roma, Italy \\ ${ }^{2}$ CNRS, UMR6249, Laboratoire Chrono-Environnement, 16 route de Gray, 25030 Besançon cedex, France \\ ${ }^{3}$ CBAE, UMR5059, CNRS, Université Montpellier 2, Montpellier, France \\ ${ }^{4}$ Dipartimento di Scienze della Terra, Università di Pisa, Via S. Maria 53, 56126 Pisa, Italy \\ ${ }^{5}$ EA 6293 GéHCO, Université de Tours, 37000 Tours, France
}

Correspondence to: L. Sadori (laura.sadori@uniroma1.it)

Received: 23 March 2013 - Published in Clim. Past Discuss.: 8 April 2013

Revised: 10 July 2013 - Accepted: 12 July 2013 - Published: 19 August 2013

\begin{abstract}
The aim of this study is to investigate climate changes and human activities under the lens of palynology. Based on a new high-resolution pollen sequence (PG2) from Lago di Pergusa (667 m a.s.l., central Sicily, Italy) covering the last $6700 \mathrm{yr}$, we propose a reconstruction of climate and landscape changes over the recent past in central Sicily. Compared to former studies from Lago di Pergusa (Sadori and Narcisi, 2001), this work provides a reconstruction of the evolution of vegetation and climate over the last millennia in central Sicily, indeed completing previous results with new pollen data, which is particularly detailed on the last $3000 \mathrm{yr}$.

Joint actions of increasing dryness, climate oscillations, and human impact shaped the landscape of this privileged site. Lago di Pergusa, besides being the main inland lake of Sicily, is very sensitive to climate change and its territory was inhabited and exploited continuously since the Palaeolithic. The lake sediments turned out to be a good observatory for natural phenomena that occurred in the last thousands of years.

Results of the pollen-based study are integrated with changes in magnetic susceptibility and a tephra layer characterization. The tephra layer was shown to be related to the Sicanians' event, radiocarbon dated at $3055 \pm 75 \mathrm{yr} B P$ (Sadori and Narcisi, 2001).

We performed palaeoclimate reconstructions by MAT (Modern Analogues Technique) and WAPLS (Weighted Average Partial Least Square). Palaeoclimate reconstructions based on the core show important climate fluctuations throughout the Holocene. Climate reconstruction points
\end{abstract}

out four phases of cooling and enhanced wetness in the last three millennia (2600-2000, 1650-1100, 850-550, 400$200 \mathrm{cal} \mathrm{BP}$, corresponding to the periods between 650 $50 \mathrm{BC}$, and 300-850, 1100-1400, 1550-1750 AD, respectively). This appears to be the evidence of local responses to global climate oscillations during the recent past.

\section{Introduction}

In the present-day debate concerning possible effects of the ongoing climate change, the understanding of biological responses to past climate variations assumes a great interest. Open questions remain on local responses to global climate changes during the recent past and possible evolution under future climate forcing (IPCC, 2007; Giorgi and Lionello, 2008). Palaeoclimate reconstruction gives a basis for predicting and limiting the effects of global warming on local vegetation and climate in highly sensitive areas.

Although the high interest for the understanding of climatic and environmental evolution under Mediterranean conditions, due to the scarcity of sites suitable for palaeoecological analyses there are only a few works that retrace the vegetation and climate history of the south-central Mediterranean. Besides, they underline an important spatial variability of landscapes and local responses to climate changes (de Beaulieu et al., 2005; Carrión et al., 2010a, b; Magny et al., 2012, 2013). In this context, understanding responses to climate changes in Sicily, the largest Mediterranean island, is 
particularly interesting, as its central geographic position in the Mediterranean Basin makes it a key region for the understanding of Holocene climates and environments. Important and expected differences are found in Sicily itself, in particular between the inland and the coast (Noti et al., 2009; Sadori and Narcisi, 2001; Tinner et al., 2009). Sicily has been inhabited since the Palaeolithic and interactions between climate changes and human activities have to be expected. It is clear that in such sites a close relationship between humans and their environment exists, but the way individuals or groups adapt to or impact their environment (or do both) must be considered on a different scientific base, case by case (Mercuri et al., 2010, 2011; Sadori et al., 2010a, b). To do this, a particular attention to the natural features of the site and to its human history was paid in this study.

In particular, Lago di Pergusa is, both for geographic location and human history, in a crucial and privileged position to study the landscape changes occurred since prehistory.

This peculiarity of Sicily is mainly due to the strong seasonality and the heterogeneity of its climate (Zampino et al., 1997), the high rate of biodiversity and endemism (Brullo et al., 1995, 1996; Di Pasquale et al., 1992; Quezel et al., 1993), the long human history (Bernabò Brea, 1961) and the progressive aridification of last millenaries recorded in former studies (e.g. Frisia et al., 2006; Magny et al., 2011, 2012; Pérez-Obiol and Sadori, 2007; Sadori and Narcisi, 2001).

\section{Study area}

Lago di Pergusa is located in central Sicily, Southern Italy $\left(37^{\circ} 31^{\prime} \mathrm{N} ; 14^{\circ} 18^{\prime} \mathrm{E}\right)$, at $667 \mathrm{~m}$ a.s.l. (Fig. 1a). The study site features were already described (Sadori and Narcisi, 2001 and therein references) and are hereafter summarized. The lake (surface area $0.5 \mathrm{~km}^{2}$, catchment ca. $7.5 \mathrm{~km}^{2}$ ) occupies an endorheic basin with catchment composed by Pliocene marine deposits, i.e. sandstone and claystone. It is solely fed by rainfall and groundwaters and has experienced strong lake level variations imputed to evapotranspiration. This phenomenon made it very sensitive to seasonal and long-term climatic variations. At present the lake level surface is controlled.

Climate in the area of Pergusa is cooler and moister than along the coast, with annual precipitation between $500-700 \mathrm{~mm}$ and mean annual temperature of $13.4^{\circ} \mathrm{C}$ (Enna weather station). Archive data from three meteorological stations show that precipitation decreased during the second half of the last century. The lake is particularly vulnerable to climate changes, lying at present at the border of three areas with different aridity indices (Fig. 1b, Duro et al., 1997). The lacustrine vegetation (Fig. 1c, Calvo et al., 1995) before the recent water body regulation, consisted in several concentric belts: a wide (by some meters) external belt (Fig. 1c, a), of almost only Phragmites australis (Cav.) Trin., an inner discontinuous belt (Fig. 1c, b) of halophilous plants characterized by Juncus maritimus Lam., and an internal ephemeral zone directly depending on the lake level fluctuations and constituted by halophilous and seasonal plant communities (c, d, and e belts). These are mainly characterized by chenopods as Atriplex latifolia Wahlenb. (belt c), Suaeda maritima (L.) Dumort. (belt d) and Salicornia patula Duval-Jouve as well as many nitrophilous Asteraceae, both Asteroideae and Cichorioideae (belt e). The lake is at present surrounded by open landscapes dominated by xerophytic grasslands (Pignatti, 1994) and crop cultures, often abandoned. The only traces of natural vegetation are represented by rare trees of Quercus virgiliana (Ten.) Ten., Quercus ilex L., Quercus pubescens Willd., Quercus suber L. and Rhamnus alaternus $\mathrm{L}$.

Human activity has been documented in central Sicily since the Palaeolithic Age (Tusa, 1992) and there have been recent findings just nearby Lago di Pergusa (Giannitrapani, 2012a). Mesolithic Age sites have not yet been discovered in the area, and Neolithic (the period is dated from 6000 to $3500 \mathrm{yr} \mathrm{BC}$ in the area) ones are quite rare. Traces of Neolithic Age in the surroundings of Pergusa date back to ca. $5000 \mathrm{yr} \mathrm{BC}$ and according to the archaeologists they can be referred to small nomad populations devoted to hunting and gathering. Even if the number of Neolithic sites was increasing at the end of the period, the shepherds were still using transhumance and did not know agriculture as in other regions of Southern Italy (Giannitrapani, 2012a). The Eneolithic Age (from 3500 to $2300 \mathrm{yr}$ BC in Sicily) is documented at Cozzo Matrice, on the edge of the catchment of the lake, by the presence of a hut ascribed to an initial phase of the period. The site, located on a hill, became a necropolis during Greek times (Giannitrapani, 2012a). It was in the final period of the Eneolithic and at the beginning of the Bronze Age that a massive boost was given to the number of settlements in the region of Enna (Giannitrapani, 2012a, b). In the catchment of Fiume Imera Meridionale (east of Pergusa) $60 \%$ of the prehistoric sites are dated between the late Eneolithic and the Early Bronze Age (from ca. 2600 to $2000 \mathrm{yr} \mathrm{BC}$ ). The number of the sites decreased at the beginning of the Middle Bronze Age (at ca. $1500 \mathrm{yr}$ BC), to recover between 1200 and $700 \mathrm{yr} B C$, at the passage from Bronze to Iron Age. In the close surroundings of the lake (Fig. 1d) the Bronze and Iron Age periods are in fact well documented (Bernabò Brea, 1961; Giannitrapani and Pluciennik, 1998; Tusa, 1992). Diodorus Siculus (Library of History, V, 6, 2-4) reported that the area of Pergusa around $3000 \mathrm{yr}$ ago was first settled by Sicanians, then by Sicels. Since the Iron Age in fact the area around Pergusa has been continuously inhabited, being at the border between different populations that alternated in the territory: Sicels and Sicanians conteded the supremacy during the Iron Age, and Carthaginians and Greeks battled many times to conquer Enna. The area was an intense hub of trade among Greek towns, the administrative border between eastern and western Sicily when it became a Roman province, and again a 


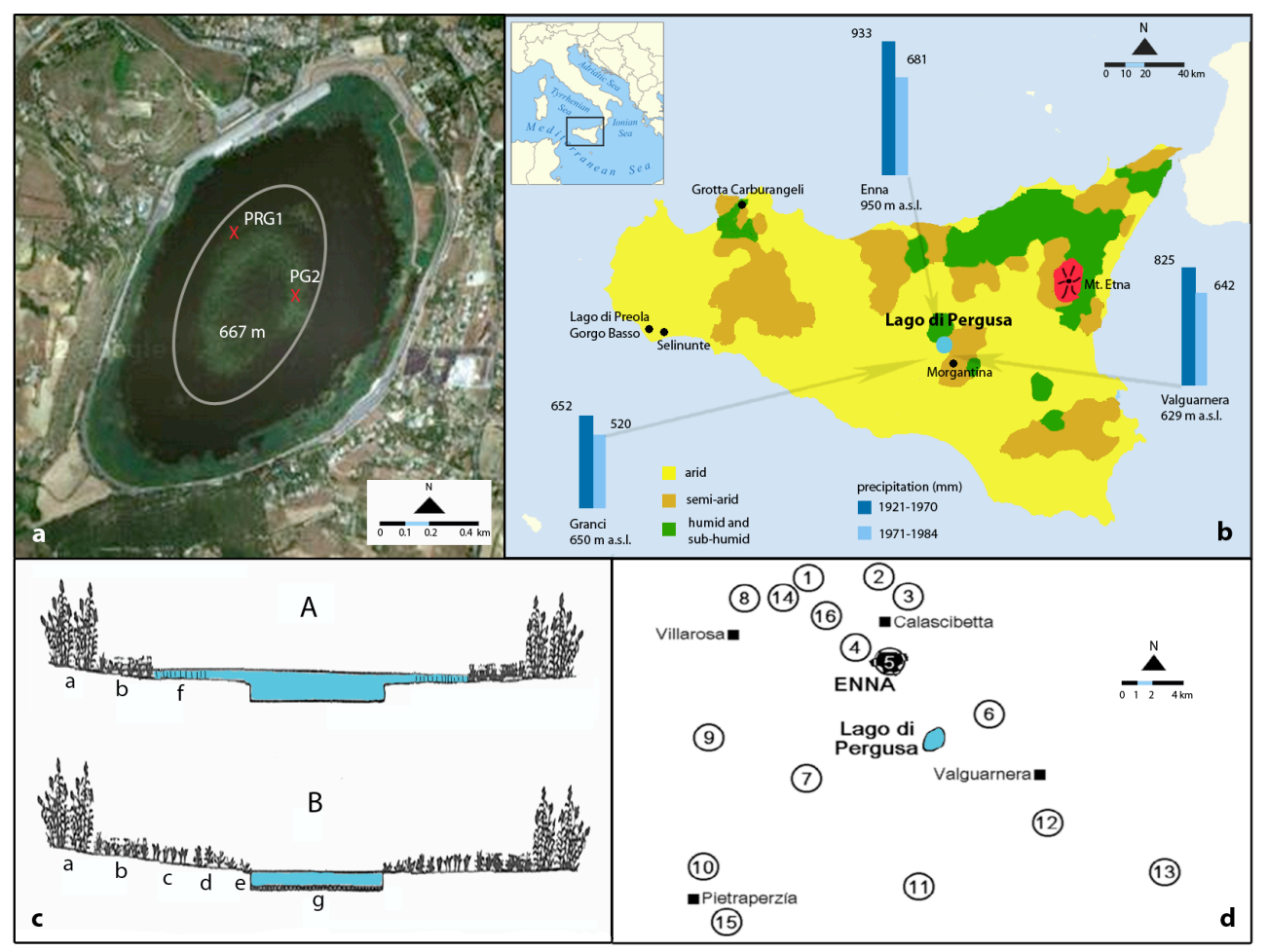

Fig. 1. (a) Lago di Pergusa: location map of cores PG2 and PRG1. The ellipsis roughly marks the lake perimeter when core PRG1 (Sadori and Narcisi, 2001) was sampled. (b) Aridity map of Sicily and selected mean annual precipitation for three selected meteorological stations (from Duro et al., 1997, redrawn). (c) Sketches of lacustrine vegetation: (A) maximum lake level, (B) minimum lake level. Dominant taxa of the lacustrine vegetation concentric belts: (a) Phragmites australis, (b) Juncus maritimus, (c) Atriplex latifolia, (d) Suaeda maritima, (e) Salicornia, (f) Chara; (g) microbial mat (from Calvo et al., 1995, modified). (d) Main archaeological sites around Lago di Pergusa: (1) Case Bastione (Neolithic Age, Copper Age); (2) Realmese (Bronze Age, Iron Age); (3) Malpasso (Iron Age); (4) Calcarella (Bronze Age, Iron Age); (5) Enna (Copper Age, Bronze Age, Greek period, Middle Ages); (6) Cozzo Matrice (Copper Age, Greek period); (7) Riparo di Contrada S. Tommaso (Bronze Age); (8) Monte Giulfo (Greek period); (9) Capodarso (Copper Age, Bronze Age, Greek period); (10) Rocche (Greek period); (11) Montagna di Marzo (Greek period); (12) Rossomanno (Greek period, Middle Ages); (13) Morgantina (Greek and Roman periods); (14) Contrada Gaspa (Roman period); (15) Contrada Runzi (Roman period); (16) Canalotto (Middle Ages) (from Sadori and Giardini, 2008, modified).

crossroad among three valleys (Val di Mazara, Val di Noto and Val Demone) in the Middle Ages (Giannitrapani, 2012a). Under the Romans that conquered Sicily with the battle against Carthaginians at Egadi Islands (241 BC), a first garrison was established in Enna (Castrum Hennae), which soon became a rich and important centre for wheat trade and remained so also under the Byzantines (since 5th/6th c. AD) and the Arabs (since 9th c. AD) that named the town Casrjani. Normans, Swabians, and Spanish were then in turn in Enna and controlled its territory.

\section{Methods}

\subsection{The sediment core}

A $6.26 \mathrm{~m}$ long sediment record (composed core PG2) was retrieved from Lago di Pergusa (Fig. 1a) in 2006 using a UWITEC coring platform with a percussion piston coring technique at $2.5 \mathrm{~m}$ of water depth. At the time of the drilling the water level was already controlled. Particular care was paid to recover and store the top decimetres with a gravity corer. Twin cores were retrieved, and segments were extracted and stored at $4{ }^{\circ} \mathrm{C}$ at the University of Franche-Comte (France).

Magnetic susceptibility (MS) was measured in the cores at $5 \mathrm{~mm}$ resolution with a Geotek multi-sensor core logger (Gunn and Best, 1998). MS was measured on split cores with the MS2E1 surface-scanning sensor from Bartington Instruments, which was adapted for fine-resolution volume magnetic-susceptibility measurements (Vannière et al., 2004). These analyses allow us to establish stratigraphic correlations useful for constructing the master sequences (PG2), guaranteeing complete records without any gaps or redundancies. Detailed sediment analyses are still in progress. 


\subsection{Dating}

Plant macrofossils were not visible to the naked eye, so several sediment samples were processed to find plant macroremains suitable to be radiocarbon-dated. Four plant samples (two seed samples ascribed to Scirpus sp. and two wood fragments) have been selected for AMS radiocarbon analysis.

A tephra layer, highlighted by magnetic susceptibility, was morphologically and geochemically analyzed. The sediment was washed, filtered, dried and then embedded in epoxy resin and screened for glass shard fragments using scanning electron microscopy (SEM). Energy-dispersivespectrometry (EDS) analyses of glass shards and scoriae fragments were performed using an EDAX-DX microanalyser mounted on a Philips SEM 515 at the Dipartimento di Scienze della Terra, University of Pisa, employing a $20 \mathrm{kV}$ acceleration voltage, $100 \mathrm{~s}$ live time counting, 2100-2400 shots per second, and ZAF correction. To avoid alkali loss, especially $\mathrm{Na}$, a window spot was used (usually with side ca. $10 \mu \mathrm{m})$. Performance of the instrument is extensively discussed elsewhere, especially in comparison with wave dispersion spectroscopy (Caron et al., 2010; Cioni et al., 1997; Marianelli and Sbrana, 1998; Sulpizio et al., 2010; Vogel et al., 2009), indicating comparable performances on major elements, and will not be discussed further. To perfectly compare our data with those obtained by Sadori and Narcisi (2001), the tephra layer found in core PRG1 was resampled and re-analyzed.

\subsection{Pollen analysis}

Pollen extraction from the sediment samples followed Goeury and de Beaulieu (1979). Three hundred (300) terrestrial pollen grains were counted on average under a transmitted light microscope at a magnification of 400X. Pollen grain identification was based on photographs (Reille, 1992, 1995, 1998) and on the reference collection of Laboratoire ChronoEnvironnement (Franche-Comté University, France). Quercus cf. suber curve can also comprehend $Q$. cerris pollen, as the two are morphologically undistinguishable. Pollen percentages were calculated on the basis of total arboreal (AP) and non-arboreal (NAP) terrestrial pollen grains. Pollen concentration values were estimated according to Cour (1974). Pollen diagrams were drawn using C2 program (Juggins, 2003). Ages are always expressed in calendar years BP; an additional time scale in years BC/AD is present in Figs. 4 and 5 .

\subsection{Climate reconstruction}

Climate reconstructions inferred from pollen data are based on two different approaches: the modern analogue technique "MAT" (Guiot, 1990), based on a comparison of past assemblages to modern pollen assemblages, and the weighted average-partial least square method WAPLS developed by ter Braak and Juggins (1993) which requires a real statistical calibration. The MAT has been used in a number of studies focusing Mediterranean regions (e.g. Desprat et al., 2013; Peyron et al., 2011, 2013; Pross et al., 2009) and the WAPLS has recently been successfully tested in Mediterranean regions (Finsinger et al., 2010; Peyron et al., 2013), showing its reliability in linking modern pollen data to climate in the Italian area (Finsinger et al., 2007). More details on these two methods are given in Peyron et al. (2013). For the MAT and the WAPLS, we use the modern pollen dataset developed by Dormoy et al. (2009) restricted to the Mediterranean area (longitude: -10 to $40^{\circ}$, latitude: 30 to $45^{\circ}$ ) and containing 1146 samples. The number of selected analogues was 8 (MAT) and the number of components taken was 2 (WAPLS), based on the results of the crossvalidations (leave-one-out and bootstrap). As another validation test, we have distinguished two distinct subsets in the modern pollen database by applying a random samples selection. This step produced two modern datasets, each containing 573 samples that were used respectively for the training and the validation of transfer functions based on WAPLS and MAT methods. Statistical processing and transfer functions were performed using R, especially packages "rioja" (http://www.r-project.org/) and "bioindic" (CEREGE Website).

\section{Results}

\subsection{The core and its chronology}

Visual core description was carried out. From bottom core to $310 \mathrm{~cm}$ the sediment consists of olive grey to brownish mottled silty clay. The upper part of the core is composed of greyish silty clay and dark to very dark silty clay alternating with silty and sandy laminae. Some gradational contacts have been identified. Oxidized spots and very dark levels are present. Bioturbation and shell fragments occur at the bottom of the core. Variations in the sediment density were also highlighted by magnetic susceptibility analyses (Fig. 2). The magnetic susceptibility trend shows the presence of ashes dispersed in less than $10 \mathrm{~cm}$ of sediment of the composite core (between 465 and $475 \mathrm{~cm}$ ), corresponding to the tephra between $47-53 \mathrm{~cm}$ in the core section 01-C2. In correspondence with the ashes, magnetic susceptibility peaks at 53 (the mean SI of the record is 2.9). The tephra comprises principally dark, brown, blocky fragments. Two types of fragments can be distinguished: the rarest is characterized by a few spherical or ovoid vesicles and a prevailing glassy matrix, whereas the most common type is characterized by a crystalline groundmass mostly composed by plagioclase, and to a lesser extent by pyroxene and rarely by olivine. Ti-Fe oxides are also present. In this second type, glass is usually interstitial or can be absent. This makes the analyses particularly complex, producing a dispersion of chemical data of 


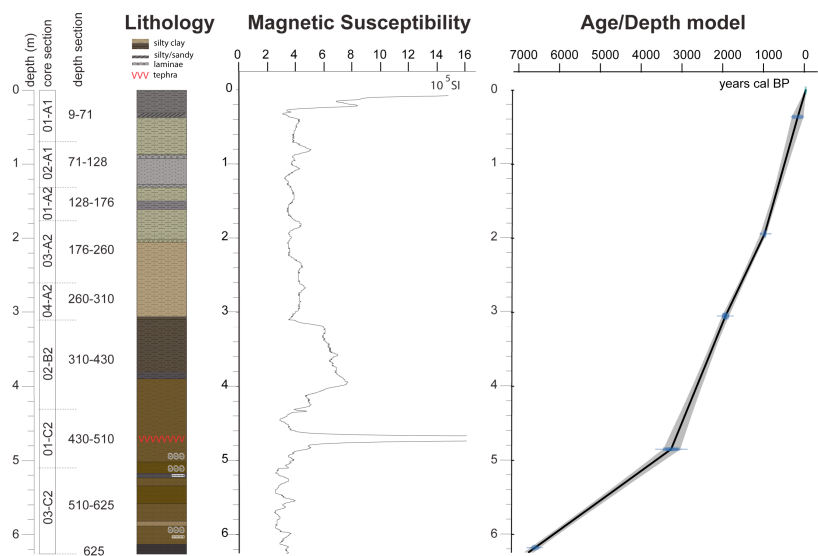

Fig. 2. Lago di Pergusa: PG2 core. Lithology, uncalibrated volume susceptibility, linear interpolation of AMS calibrated dates. A thin black layer, observed in the section 01-C2, corresponds to the ash event dated in PRG1 at $3055 \pm 75 \mathrm{yr}$ BP (Sadori and Narcisi, 2001).

the glassy matrix (Table 1). Compositionally, a single shard ranges principally from mugeritic and benmoreitic field, partially straddling the photephritic compositions.

The tephra characteristics and its chemical composition perfectly match with those determined by Sadori and Narcisi (2001), and particularly with the new set of data produced for comparison (Fig. 3, Table 1). As extensively discussed by Sadori and Narcisi (2001) the features of the tephra at Lago di Pergusa are similar to that from the Etna Volcano eruption, which was strong enough to make ashes reach the Balkans (Sulpizio et al., 2010; Wagner et al., 2008), and which was dated to $3150 \pm 60 \mathrm{yr}$ BP by radiocarbon on charred material from the top of the eruption (Coltelli et al., 2000). In core PRG1 Sadori and Narcisi (2001) obtained an age of $3055 \pm 75 \mathrm{yr}$ BP just below the tephra layer.

The four radiocarbon ages obtained from macroremains are consistent with the radiocarbon age available for the tephra (Sadori and Narcisi, 2001) and were used to elaborate an age/depth model based on linear interpolation (Fig. 2, Table 2).

Calculations were done using the program Clam (Blaauw, 2010), which calibrated the ${ }^{14} \mathrm{C}$ and tephra-inferred dates following IntCal09 (Reimer et al., 2009). The new core PG2 covers the last 6700 calendar years. Figure 2 shows a lower sedimentation rate of core PG2 in the deeper part of the core, and an increase since 3000 cal BP, appearing "constant" until present-day. Ages are expressed as calendar years BP (cal BP) unless differently stated.

\subsection{Pollen results}

A total of 123 pollen and spore types (including 35 tree and shrub taxa and 75 herbs) were identified. Due to the high sedimentation rate of the last $3000 \mathrm{yr}$, quite good detail is obtained for the period, with an average of a sample every

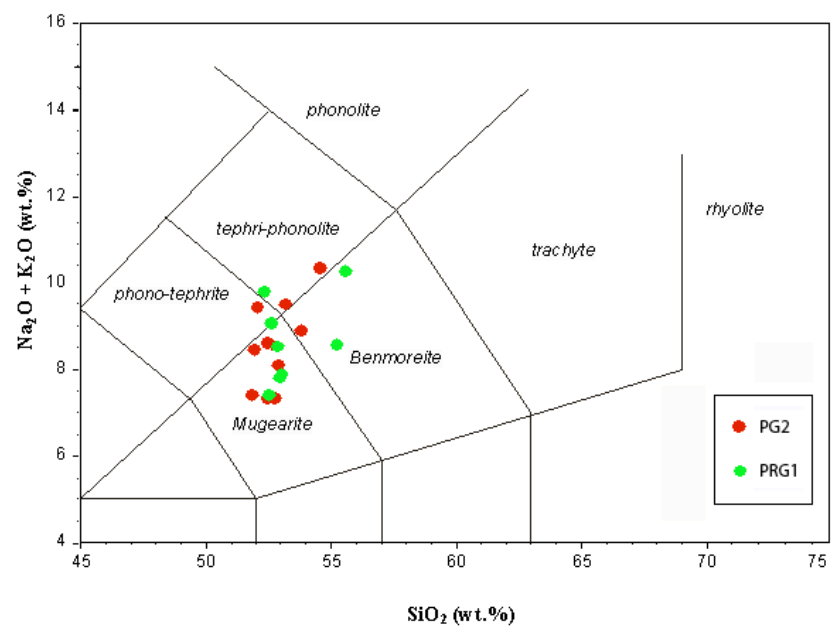

Fig. 3. Lago di Pergusa: total alkali vs. silica diagram (Le Bas et al., 1986) for tephra in Pergusa cores (PRG1 and PG2).

$6 \mathrm{~cm}$ (i.e. interval between samples is ca. $50 \mathrm{yr}$ ). Data from core PG2 are shown in Figs. 4 (arboreal and non-arboreal taxa) and 5 ("ecological groups" and total concentration).

\subsubsection{Pollen Zone 1 (PZ1)}

Pollen Zone 1 (PZ1) ranges from 626 to $570 \mathrm{~cm}$ (ca. 6730$5375 \mathrm{cal} \mathrm{BP})$. The bottom of the sequence is radiocarbon dated to $5780 \pm 40 \mathrm{yr}$ BP. AP are between 60 and $80 \%$, pollen concentration, always intended as pollen grains/g ranges from 19000 to 135000 , and the number of taxa from 27 to 37. Deciduous (Quercus robur tp.) and evergreen oak (Quercus ilex tp.) pollen (both peaking at $45 \%$ ), olive tree (Olea) and elm (Ulmus) between 5 to $10 \%$, beech (Fagus) and hazel (Corylus) at less than $5 \%$ are the main taxa. Arboreal pollen is dominant in this pollen zone and Poaceae do not represent more than $20 \%$ of the total pollen. Among non-arboreal taxa, cerealia, Ranunculaceae, Chenopodiaceae, Plantago, Rumex, Artemisia, Cichorioideae undiff., Apiaceae, Asteroideae undiff. and Lamiaceae are continuously recorded, with percentages higher than $1 \%$, since the bottom of the core.

\subsubsection{Pollen Zone 2 (PZ2)}

Pollen Zone 2 (PZ2) ranges from 570 to $470 \mathrm{~cm}$ (ca. 5375$3150 \mathrm{cal}$ BP). The Sicanian's tephra layer, radiocarbon dated at $3055 \pm 75 \mathrm{yr}$ BP in core PRG1 was detected between ca. 465 and $475 \mathrm{~cm}$. AP are between 30 and $65 \%$, pollen concentration ranges from 12000 to 110000 , and the number of taxa from 28 to 45 . The transition to this pollen zone is marked by an abrupt decrease of AP from 80 to $50 \%$, involving both oak pollen types (from $>30 \%$ to $<5 \%$ ) and a relative increase of Poaceae (ca. 10 to $30-40 \%$ ), becoming dominant from this zone to the top of the sequence; several herbs (in particular Chenopodiaceae, Plantago, Ranunculaceae, Apiaceae, Asteroideae undiff., Artemisia) show a 
Table 1. Lago di Pergusa: chemical data for the tephra layer from core PG2 (this paper) and PGR1 (Sadori and Narcisi, 2001). Samples from PRG1 were newly analysed.

\begin{tabular}{|c|c|c|c|c|c|c|c|c|c|c|c|c|c|c|}
\hline & $\mathrm{SiO}_{2}$ & $\mathrm{TiO}_{2}$ & $\mathrm{Al}_{2} \mathrm{O}_{3}$ & $\mathrm{FeO}_{\text {tot }}$ & $\mathrm{MnO}$ & $\mathrm{MgO}$ & $\mathrm{CaO}$ & $\mathrm{Na}_{2} \mathrm{O}$ & $\mathrm{K}_{2} \mathrm{O}$ & $\mathrm{P}_{2} \mathrm{O}_{5}$ & $\mathrm{ClO}$ & Total & $\mathrm{K}_{2} \mathrm{O}+\mathrm{Na}_{2} \mathrm{O}$ & $\mathrm{K}_{2} \mathrm{O} / \mathrm{Na}_{2} \mathrm{O}$ \\
\hline PG2-2 & 54.59 & 2.40 & 17.53 & 7.31 & 0.32 & 2.07 & 4.49 & 5.82 & 4.54 & 0.55 & 0.38 & 100 & 10.36 & 0.78 \\
\hline PG2-3 & 53.81 & 1.78 & 17.67 & 8.26 & 0.05 & 3.09 & 5.67 & 5.15 & 3.77 & 0.5 & 0.25 & 100 & 8.92 & 0.73 \\
\hline PG2-4 & 52.47 & 1.95 & 16.65 & 9.84 & 0.19 & 3.42 & 7.38 & 4.76 & 2.59 & 0.52 & 0.23 & 100 & 7.35 & 0.54 \\
\hline PG2-5 & 52.09 & 1.94 & 16.58 & 9.74 & 0.17 & 3.36 & 5.94 & 5.27 & 4.20 & 0.48 & 0.23 & 100 & 9.47 & 0.80 \\
\hline PG2-6 & 52.86 & 1.90 & 17.31 & 9.09 & 0.16 & 3.22 & 6.16 & 4.20 & 4.74 & 0.58 & 0.18 & 100 & 8.54 & 0.80 \\
\hline PG2-7 & 51.86 & 1.95 & 16.98 & 10.34 & 0.17 & 3.42 & 7.24 & 4.61 & 2.82 & 0.38 & 0.23 & 100 & 7.43 & 0.61 \\
\hline PG2-9 & 52.47 & 2.07 & 16.46 & 9.56 & 0.35 & 3.43 & 6.48 & 5.06 & 3.57 & 0.34 & 0.21 & 100 & 8.63 & 0.71 \\
\hline PG2-10 & 52.81 & 1.97 & 16.73 & 9.80 & 0.21 & 3.52 & 6.94 & 4.49 & 2.88 & 0.43 & 0.22 & 100 & 7.37 & 0.64 \\
\hline PG2-11 & 52.92 & 2.21 & 16.19 & 9.97 & 0.32 & 2.95 & 6.60 & 5.10 & 3.04 & 0.42 & 0.28 & 100 & 8.14 & 0.60 \\
\hline PG2-12 & 53.21 & 2.12 & 16.78 & 9.81 & 0.38 & 3.29 & 4.16 & 5.14 & 4.40 & 0.41 & 0.30 & 100 & 9.54 & 0.86 \\
\hline PG2-13 & 51.98 & 2.11 & 16.53 & 10.06 & 0.26 & 3.55 & 6.36 & 4.74 & 3.73 & 0.52 & 0.16 & 100 & 8.47 & 0.79 \\
\hline PRG1-1 & 55.56 & 2.04 & 16.72 & 9.16 & 0.19 & 3.42 & 6.17 & 4.88 & 4.20 & 0.51 & 0.15 & 100 & 9.08 & 0.86 \\
\hline PRG1-2 & 55.56 & 2.44 & 16.23 & 8.58 & 0.10 & 2.22 & 3.63 & 5.31 & 4.98 & 0.78 & 0.17 & 100 & 10.29 & 0.97 \\
\hline PRG1-3 & 55.19 & 2.12 & 16.53 & 9.46 & 0.07 & 2.60 & 4.53 & 4.36 & 3.97 & 0.44 & 0.46 & 100 & 8.6 & 0.86 \\
\hline PRG1-5 & 52.31 & 2.00 & 16.72 & 8.84 & 0.20 & 3.18 & 6.30 & 5.47 & 4.36 & 0.45 & 0.17 & 100 & 9.83 & 0.80 \\
\hline PRG1-6 & 52.84 & 2.01 & 16.31 & 9.95 & 0.10 & 3.25 & 6.27 & 4.86 & 3.71 & 0.46 & 0.24 & 100 & 8.57 & 0.76 \\
\hline PRG1-6b & 52.99 & 2.16 & 16.07 & 10.2 & 0.27 & 3.33 & 6.45 & 4.47 & 3.42 & 0.42 & 0.22 & 100 & 7.89 & 0.76 \\
\hline PRG1-7 & 52.94 & 1.90 & 16.94 & 9.2 & 0.28 & 3.56 & 6.74 & 5.18 & 2.65 & 0.40 & 0.21 & 100 & 7.83 & 0.51 \\
\hline PRG1-8 & 52.53 & 2.18 & 16.55 & 9.77 & 0.31 & 3.47 & 7.19 & 4.66 & 2.76 & 0.38 & 0.20 & 100 & 7.42 & 0.59 \\
\hline
\end{tabular}

slight increase. Undifferentiated cereals and Secale are currently recorded from this zone up to top core. Papaver and Centaurea cyanus pollen grains are recorded at the end of the zone. The zone is also characterized by the continuous presence of Cyperaceae (more than 1\%). Pollen percentages of dominant taxa (Quercus deciduous and evergreen types and Poaceae) show important and rapid variations within this zone; Olea and Ulmus show low percentages but also slight variations. Fagus and Quercus cf. suber are recorded continuously.

\subsubsection{Pollen Zone $3($ PZ3)}

Pollen Zone 3 (PZ3) is split into two subzones, PZ3a and PZ3b. In PZ3 AP are between 45 and $65 \%$, pollen concentration ranges from 16000 to 85000 , and the number of taxa from 26 to 52. Pollen subzone 3a (PZ3a: $470-445 \mathrm{~cm}$; ca. $3150-2950$ cal BP). AP are between 50 and $65 \%$. This short zone is characterized by the sudden increase of Olea to ca. $20 \%$, while both Quercus dominant pollen types decrease as well as Ulmus. Poaceae and Chenopodiaceae decrease, while other herbs do not show significant changes. Pollen subzone 3b (PZ3b: 445-410 cm; ca. 2950-2700 cal BP). AP are between 45 and $60 \%$. Olea, dominating the previous subzone, shows a strong decrease. It seems first replaced by Quercus ilex type and Pistacia, then by Quercus pubescens type. Ephedra fragilis is continuously present from this zone to the top of the diagram. Poaceae also tend to increase despite many rapid variations. Among other herbs, Chenopodiaceae do not show significant changes.
Table 2. Lago di Pergusa (core PG2): AMS radiocarbon dates.

\begin{tabular}{lllll}
\hline $\begin{array}{l}\text { Laboratory } \\
\text { code }\end{array}$ & Material & Depth $(\mathrm{cm})$ & ${ }^{14}$ C years BP & $\begin{array}{l}\text { Calendar age } \\
\text { BP }(2 \sigma)\end{array}$ \\
\hline Poz-36022 & wood & 36 & $130 \pm 30$ & $57-151$ \\
Ua-42145 & seeds & 194 & $1032 \pm 30$ & $911-988$ \\
Ua-42146 & seeds & $302-310$ & $1961 \pm 33$ & $1863-1989$ \\
Poz-36023 & wood & 618 & $5780 \pm 40$ & $6485-6670$ \\
\hline
\end{tabular}

\subsubsection{Pollen zone 4 (PZ4)}

Pollen zone 4 (PZ4) ranges from 410 to $300 \mathrm{~cm}$ (ca. 2700$1885 \mathrm{cal} \mathrm{BP}$ ). AP are between 20 and $45 \%$, pollen concentration ranges from 9200 to 76000 , and the number of taxa from 32 to 46 . The top of this zone is radiocarbon dated to $1961 \pm 33$ BP. An important further opening of the wood is found, tree pollen suddenly drops from 50 to $25 \%$, showing a decrease in both mesophilous (deciduous oaks and elm) and Mediterranean taxa (evergreen oaks, olive). Two shrub taxa show increase, namely Pistacia and Ephedra fragilis. A strong increase in anthropogenic pollen is worthy of mention. Poaceae are mainly between 25 and $35 \%$, showing many rapid variations. It is important to note the increase of Chenopodiaceae, first matching the one of Cichorioideae, and Asteroideae undiff. A consistent peak of Cichorioideae (20\%) just precedes a slight expansion of Cyperaceae, becoming more important towards the top of the diagram. The end of the zone is marked by an abrupt peak of Chenopodiaceae $(40 \%)$. 


\section{Lago di Pergusa (central Sicily)}

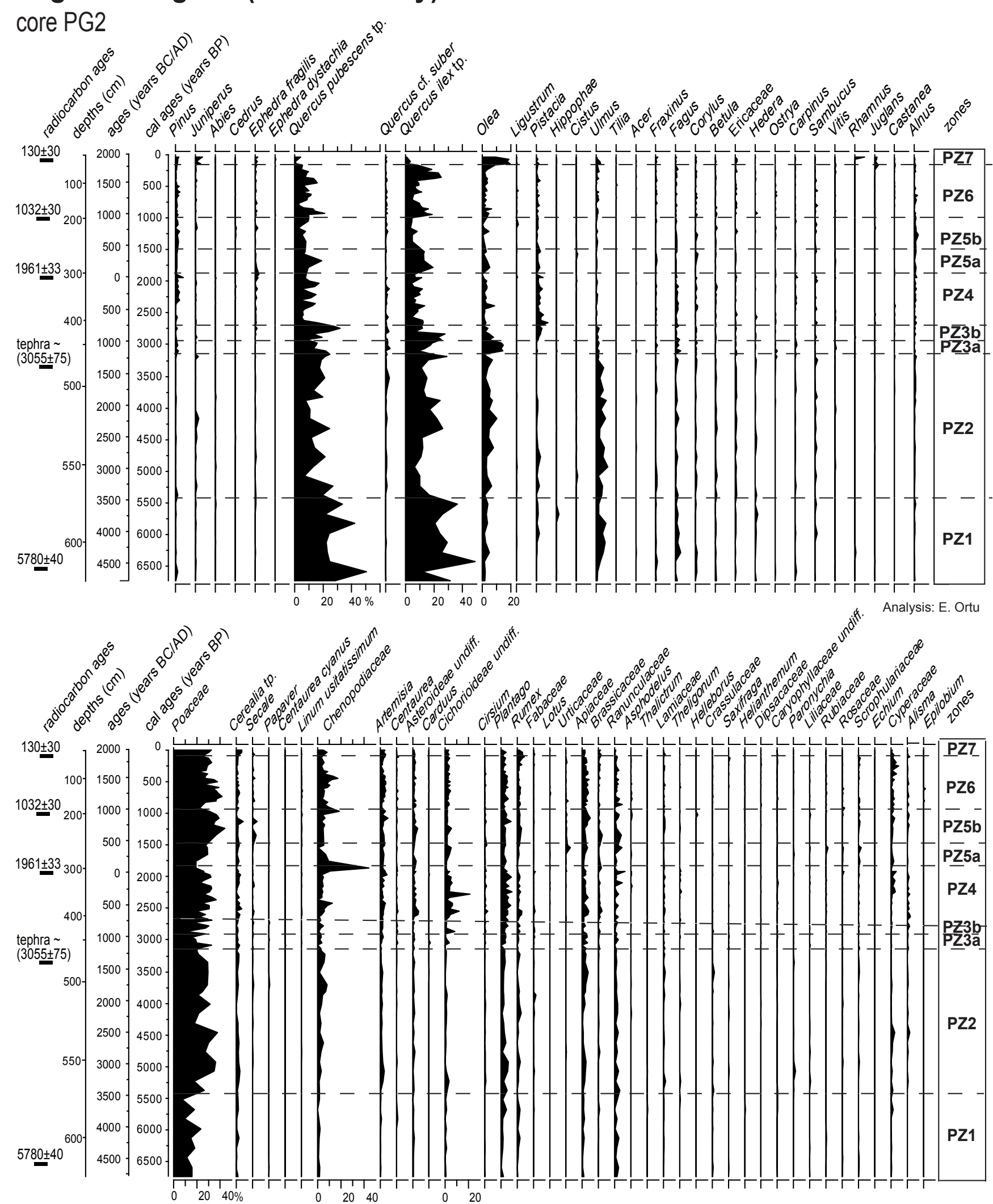

Fig. 4. Lago di Pergusa: pollen percentage diagram. 


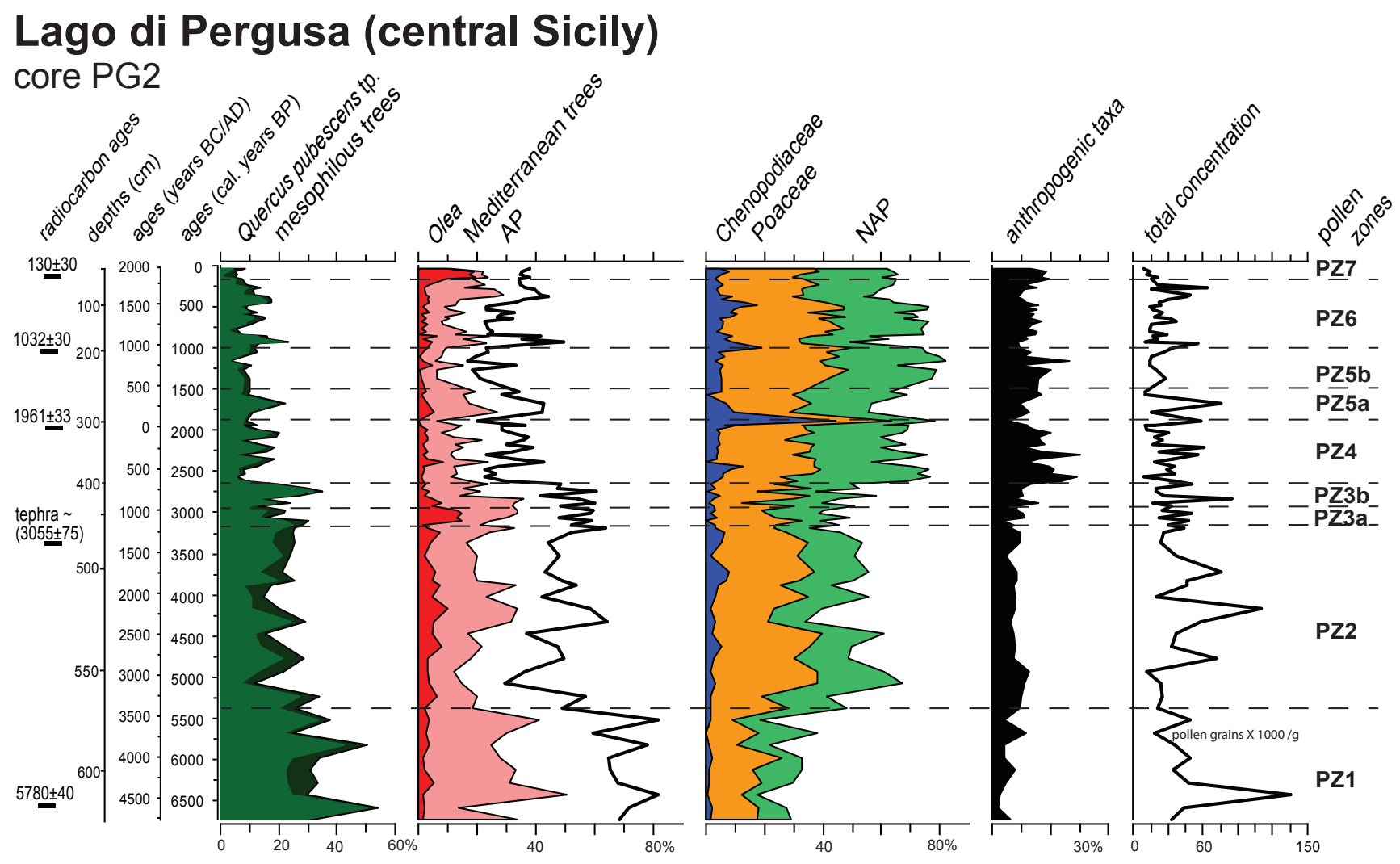

Fig. 5. Lago di Pergusa: pollen diagram. Selected cumulative curves and total pollen concentration. Mesophilous: Acer, Carpinus, Ostrya, Corylus, Fagus, Fraxinus, Quercus pubescens type, Sambucus, Tilia, Ulmus. Mediterranean: Ligustrum, Olea, Pistacia, Phyllirea, Quercus ilex, Quercus suber. Anthropogenic: Castanea, Juglans, Vitis, Asteroideae, Caryophyllaceae, Centaurea cyanus, Cerealia, Cichorioideae, Lavanda, Linum usitatissimum, Papaver, Plantago, Polygonum bistorta, Rumex, Secale, Trifolium, Urticaceae.

\subsubsection{Pollen Zone 5 (PZ5)}

Pollen Zone 5 (PZ5) ranges from 300 to $200 \mathrm{~cm}$. It is split into two subzones. AP are between 20 and $45 \%$, pollen concentration ranges from 10000 to 45000 , and the number of taxa from 33 to 48. Pollen subzone 5a (PZ5a): $300-270 \mathrm{~cm}$; ca. 1885-1620 cal BP): a slight recover of AP (>45\%), mainly due to evergreen Quercus (5 to $20 \%$ ), and followed by a slight expansion of Quercus pubescens type, marks the transition to this new zone. Poaceae show a decrease at the beginning of this zone together with other herbs. Anthropogenic taxa show a decrease too. Pollen subzone 5b (PZ5b: 270-200 cm; ca. 1620-1000 cal BP) is mainly characterized by a lowering of arboreal taxa to $20 \%$, Pistacia included, and the correspondent increase of Poaceae and anthropogenic taxa. The slight but meaningful expansion of Secale is worthy of mention. Urticaceae are continuously recorded. The zone ends with a peak of Chenopodiaceae.

\subsubsection{Pollen Zone 6 (PZ6)}

Pollen Zone 6 (PZ6) ranges from 200 to $40 \mathrm{~cm}$ (ca. 1000$170 \mathrm{cal} \mathrm{BP}$ ). The bottom of this zone is radiocarbon dated to $1032 \pm 30 \mathrm{yr}$ BP. AP are between 25 and $50 \%$, pollen concentration ranges from 3700 to 23000 , and the number of taxa from 34 to 53. This zone is characterized at its bottom by a phase of increase for both oak types, followed by an increase of Poaceae, the dominant taxon. The zone ends with an expansion of evergreen Quercus (5 to 30\%) following an increase of deciduous Quercus and of Chenopodiaceae. Anthropogenic taxa seem to be less important than in the previous two zones.

\subsubsection{Pollen Zone 7 (PZ7)}

Pollen Zone 7 (PZ7) ranges from $0.4 \mathrm{~m}$ to surface (ca. 170 cal BP to present). AP are around $40 \%$, pollen concentration ranges from 3400 to 5300 , and the number of taxa from 40 to 43 . The recovery of Olea ( $<5$ to $20 \%$ ), continuous percentages of cultivated trees (Juglans, Castanea) and percentages of $5 \%$ of Juniperus characterize this last zone. An increase in cerealia, Plantago, and anthropogenic taxa as a whole can also be noted. 


\section{Discussion}

\subsection{Comparison between PG2 and PRG1 cores}

The PRG1 core records the last $12000 \mathrm{yr}$ in $456 \mathrm{~cm}$, while the new core, PG2, spans ca. $6700 \mathrm{yr}$ in $626 \mathrm{~cm}$. Comparison of the two cores (Fig. 6) shows that they record similar vegetation dynamics, but also important differences in the temporal resolution of the last 3 millennia, confirming that a hiatus/es or a strong reduction in the sedimentation rates must be present in the upper part of core PRG1, as supposed by Sadori and Narcisi (2001). The fall of Quercus ilex and Olea (at ca. $425 \mathrm{~cm}$ in PG2 and at ca. $100 \mathrm{~cm}$ in PRG1), followed by a peak of Quercus pubescens and a slight expansion of Pistacia can be easily found in both cores, while the peaks of Quercus ilex and of Chenopodiaceae recorded in PG2 are not detected in PRG1. Considering the chenopods vegetation belts that formed in case of lake level lowering (Calvo et al., 1995, Fig. 1c) the possibility that PRG1 was taken in a periodically emerged part of the lake is advanced. Repeated lake body reductions can explain why the last $2500 \mathrm{yr}$ are recorded in $4 \mathrm{~m}$ of sediment in PG2, while this same period was entirely recorded in the upper $70 \mathrm{~cm}$ of the PRG1 core. The correlation between the two diagrams/portions comprehended between the dotted lines (Fig. 6) is clear, even if it cannot be more detailed as more than one hiatus and/or strongly reduced sedimentation periods are probably present in PRG1, and we are not able to precisely constrain them.

\subsection{Vegetation history: climate versus human forcing}

The pollen diagrams (Figs. 4 and 5) show, from bottom to top, a tendency to forest opening. Changes in forest canopy such as opening can be interpreted either as due to aridification or to (human) forest clearance. It is clear that environments such as the Pergusa are highly vulnerable and that minor climatic or human changes can provide the ignition of a never-ending drying process.

Except for the bottom of the PG2 pollen sequence (PZ1), which records a forested landscape around the site, the upper zones (PZ2 to 7) show the evolution of an open landscape dominated by Poaceae and also characterized by many other herbs. In this environment, two possibilities for understanding the Poaceae expansions have to be considered. Poaceace could have either formed vast grasslands or a hydrophilous vegetation belt around the lake itself, or both. In the first case there is a clear indication of forest opening (either human or climate induced), in the second only a climatic clue. The position of the PG2 core, neither marginal nor central in the lake like the previous PRG1 core (Sadori and Narcisi, 2001), would in fact register water body reductions (a Phragmites belt closer to the lake centre would mean increasing Poaceae percentages in the diagram) and expansions. We also have to consider that a reduction of precipitation would cause both a forest opening and the lowering of the lake level and that this climate change could have been enhanced by strong land use (e.g. forest clearance, cultivation, pasture). A clear human impact can be seen in the diagrams (Figs. 4 and 5) only since $2700 \mathrm{cal} \mathrm{BP}$ (zone 4), while since around $3700 \mathrm{yr}$ BP there is evidence of human presence, soon before the decrease of Bronze Age site numbers, around $3500 \mathrm{yr}$ BP (ca. 1500 yr BC).

As a matter of fact prehistoric populations did not change the landscape on a broad scale and a widespread human impact has been found only since the Roman period in Mediterranean environments (Mercuri et al., 2012; Roberts et al., 2011; Sadori, 2013; Sadori et al., 2004, 2011) and hardly detectable before the Bronze Age (ranging in Italy from ca. 4300 to ca. $3000 \mathrm{yr} \mathrm{BP}$ ). During the Bronze Age a number of perilacustrine settlements in the Italian peninsula were present, and the Terramare culture bloomed in the Po plain (Cremaschi et al., 2006; Mercuri et al., 2006, 2012) probably because water in that period became a less available resource (Sadori et al., 2004; Magny et al., 2007, 2009, 2011, 2012; Zanchetta et al., 2012a).

Two arguments (Sadori and Giardini, 2007, 2008) are used to explain this lack of evidence and delay in proofs coming from pollen records of the Mediterranean basin: natural vulnerability to climate change (forest clearance is not just produced by humans) and botanical issues (many anthropogenic indicators are indigenous and some others are often hard to distinguish from other plants).

Many edible plants such as cereals, pulses and fruit trees are in fact native to Mediterranean regions and their pollen grains, often not identifiable at a satisfying taxonomic level, are found during the whole Holocene and even before in the pollen diagrams. An exemplification can be made with cereal pollen type, which includes pollen of both cultivated and spontaneous cereals as well as of other grasses (Andersen, 1978). Secale (rye) is a cereal with a distinct pollen grain, distinguishable from that of other cereals. At present two species are found in the Italian flora (Pignatti, 1982): one is the cultivated S. cereale, the other is S. stricta, a Mediterranean mountain species native to Sicily (and of some central and southern Italian regions), also named mountain or wild rye and growing at 600 to $1700 \mathrm{~m}$ a.s.l. Pollen grains of the two species cannot be distinguished. Plantago lanceolata, a synanthropic herb whose finding is attentively taken into account as evidence of human presence in central Europe, has pollen grains that cannot be distinguished from those of other Plantago species indigenous in Italy (Reille, 1992).

Under this light it is not certain at all that the increase of herbs recorded at $5400 \mathrm{cal} \mathrm{BP}$ is due to forest clearance. Also the presence of Secale since $4900 \mathrm{cal}$ BP cannot be taken as an evidence of cultivation, even if the presence of one hut at Cozzo Matrice, a Copper Age site at the edge of Lago di Pergusa catchment, is documented (Fig. 1d). A different scenario is found starting in ca. $3700 \mathrm{cal} \mathrm{BP}$, when Secale and companion species of crops, like Papaver and Centaurea cyanus, as well as Linum and Vitis are found. 


\section{Lago di Pergusa (central Sicily)}

\section{core PG2}

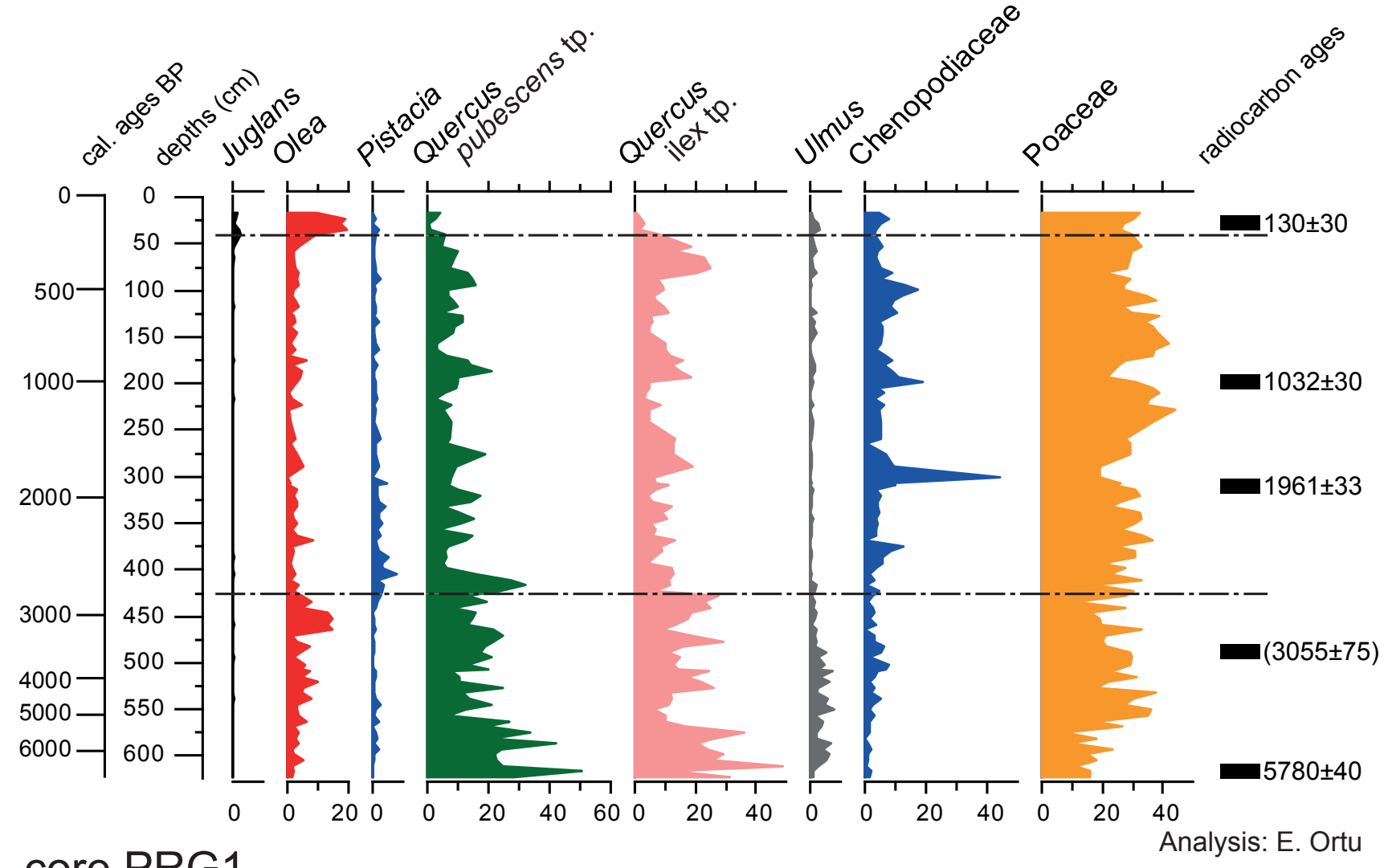

\section{core PRG1}

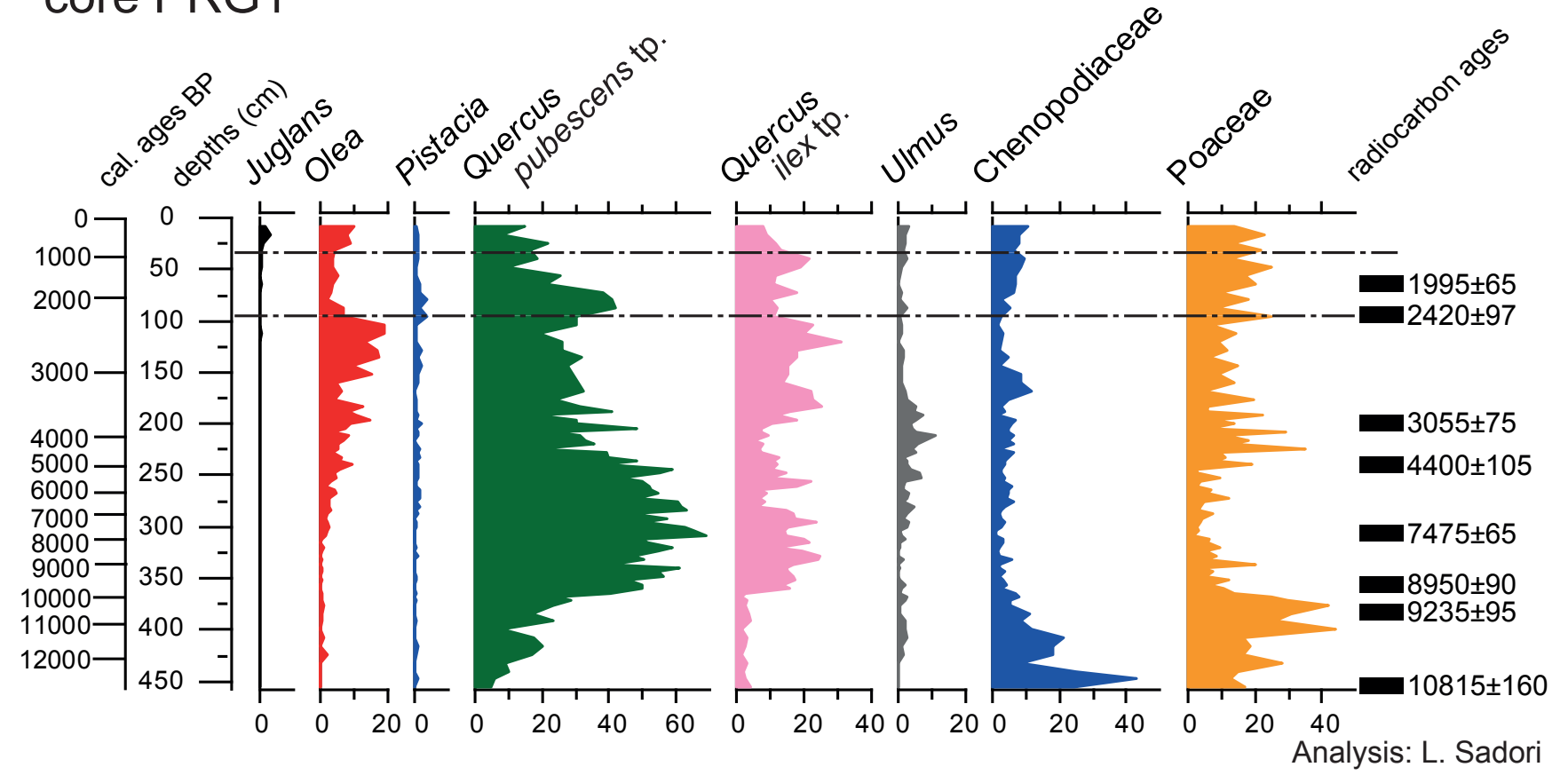

Fig. 6. Lago di Pergusa: comparison between pollen diagrams PG2 (this work) and PRG1 (Sadori and Narcisi, 2001). The diagram portions comprehended between the dotted lines probably cover the same time interval. 


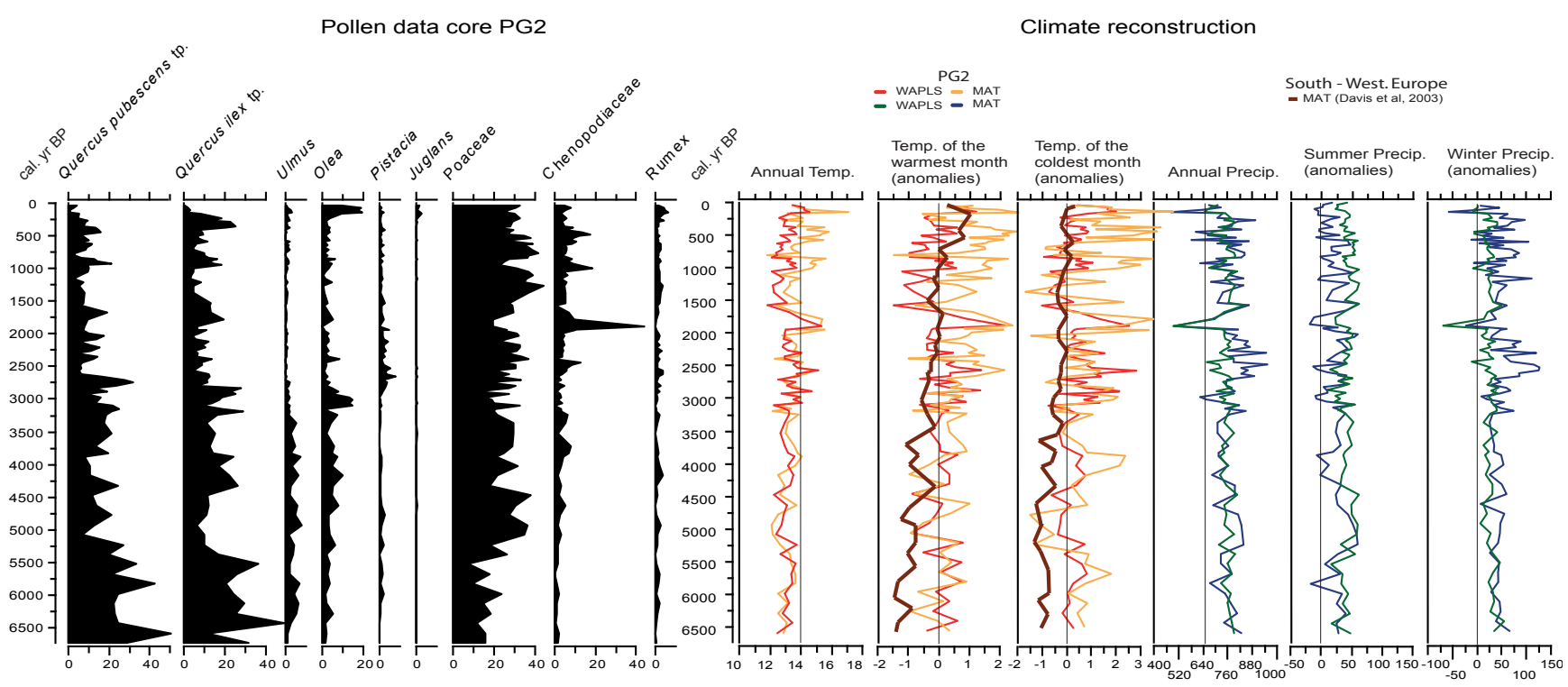

Fig. 7. Pollen-based climate reconstructions for the Pergusa PG2 with special attention to reconstructions of temperature and precipitation seasonality. Climate values are estimated using two methods: the Modern Analogues Technique (MAT), and weighted average partial least squares regression (WAPLS). Warmest and coldest month temperatures $\left({ }^{\circ} \mathrm{C}\right)$ are plotted together with the seasonal precipitation $($ winter $=$ sum of December, January, February precipitation, and summer $=$ sum of June, July, August precipitation, in mm) values. A comparison between PG2 (this study) and the reconstruction of temperatures of the warmest/coldest month (anomalies) for southern Europe (Davis et al., 2003) is also shown.

To the east of Pergusa an increase of archaeological sites is found at the passage from Copper to Bronze Age, with a decrease around $3500 \mathrm{yr} \mathrm{BP}$ and a recover at $3200 \mathrm{yr}$ BP (Giannitrapani, 2012a, b). At Lago di Pergusa an important and abrupt spread of Olea is of note from $3200 \mathrm{cal}$ BP. Wild olive tree (Olea europea var. sylvestris) is regarded as autochthonous in Sicily and requires a typical Mediterranean climate characterized by summer aridity with an average annual temperature of $14-20^{\circ} \mathrm{C}$ and precipitation varying between 300 and $1000 \mathrm{~mm} \mathrm{yr}^{-1}$ (Pignatti and Nimis, 1995). The cultivated olive tree (Olea europea) is now found in the whole area colonized by the evergreen oak forests, but the wild natural olive tree is typical of the warmest areas of Mediterranean. The findings of more than $20 \%$ of Oleapollen at Pergusa can hardly be considered as "natural". Similar percentages are in fact found at the warmer site of Gorgo Basso (Tinner et al., 2009), on the western coast of Sicily, during the phases of wild olive tree maximum development.

Even if the more obvious interpretation of pollen data points to human action as the main cause of olive expansion occurring at Pergusa between 3200 and $2800 \mathrm{cal} \mathrm{BP}$, a period in which the area was contended by Sicanians and Sicels, we have to consider that increased temperature and decreased precipitation might have favoured (or allowed) the spread of thermophilous and less moisturedemanding taxa. Cichorioideae and Asteroideae, strongly increasing since 3200 cal BP, with abundant Chenopodiaceae and overwhelming Poaceae, could in fact have formed the ephemeral vegetation belts occurring when the lake level decreased (Sect. 2, Fig. 1c) for a water shortage and a change towards drier climate conditions. In this case Cichorioideae and Asteroideae should not be considered as anthropic indicators (Figs. 4 and 5), but as dryness ones. Also mesophilous arboreal taxa like elm and deciduous oaks decrease in correspondence with the spread of olive. Olea decline is followed by a rapid succession of short increase in oaks, but it also coincides with the spread of Pistacia trees/shrubs and an increase of Ephedra fragilis (ca. $2800 \mathrm{cal} \mathrm{BP}$ ), in parallel with the definitive decline of deciduous Quercus. These elements support the hypothesis of a transition at $3200 \mathrm{cal} \mathrm{BP}$ from mixed oak forests to Mediterranean inland-forests infiltrated by typical scrub or "macchia" taxa, a sort of pioneer vegetation. The fact that Pistacia is found in both Pergusa sequences, but never more than $5 \%$, supports the hypothesis of more thermophilous and drier conditions around the site, or of intense grazing, but not the onset of the Mediterranean open vegetation, the scrubland named "macchia" in Italian.

Based on the order of these events, the record suggests successional dynamics following a human-induced perturbation of the local vegetation, whose effect might have amplified the aridification phase reconstructed in Sicily over the last three millennia by lake level oscillations (Magny et al., 2011, 2012). Stable isotope curves from previous cores from Lago di Pergusa (Sadori et al., 2008; Zanchetta et al., 2007) clearly show that the more arid period of the Holocene is found after $3000 \mathrm{cal} \mathrm{BP}$. The speleotheme portion from ca. 3600 to ca. 2800 cal BP from Grotta Carburangeli, a cave in 
Table 3. Lago di Pergusa. Climate reconstructions inferred from pollen data based on the modern analogue technique "MAT" (Guiot, 1990) and the weighted average partial least square method WAPLS developed by ter Braak and Juggins (1993).

\begin{tabular}{|c|c|c|c|c|}
\hline \multirow{2}{*}{$\begin{array}{l}\text { Climatic parameter } \\
\text { Apparent Performance }\end{array}$} & \multicolumn{2}{|c|}{ WAPLS (2 components) } & \multicolumn{2}{|c|}{ MAT (8 analogues) } \\
\hline & $r^{2}$ & RMSE & $r^{2}$ & RMSE \\
\hline Winter $T\left({ }^{\circ} \mathrm{C}\right)$ & 0.5674 & 2.8169 & 0.724 & 2.2510 \\
\hline Summer $T\left({ }^{\circ} \mathrm{C}\right)$ & 0.5085 & 2.7423 & 0.6861 & 2.1922 \\
\hline Tann $\left({ }^{\circ} \mathrm{C}\right)$ & 0.5778 & 2.5040 & 0.7225 & 2.0308 \\
\hline Winter Prec (mm/season) & 0.3105 & 77.57 & 0.5401 & 63.379 \\
\hline Summer Prec (mm/season) & 0.5799 & 48.555 & 0.8232 & 31.509 \\
\hline $\operatorname{Pann}\left(\mathrm{mm} \mathrm{yr}^{-1}\right)$ & 0.4255 & 169.84 & 0.6098 & 140.02 \\
\hline Empirical validation & $r^{2}$ & RMSE & $r^{2}$ & RMSE \\
\hline Winter $T\left({ }^{\circ} \mathrm{C}\right)$ & 0.5505 & 3.7689 & 0.6916 & 3.8203 \\
\hline Summer $T\left({ }^{\circ} \mathrm{C}\right)$ & 0.5267 & 3.3858 & 0.5842 & 3.5166 \\
\hline $\operatorname{Tann}\left({ }^{\circ} \mathrm{C}\right)$ & 0.5716 & 3.3719 & 0.6673 & 3.4569 \\
\hline Winter Prec (mm/season) & 0.2512 & 74.0907 & 0.4817 & 79.956 \\
\hline Summer Prec (mm/season) & 0.5815 & 67.2396 & 0.797 & 70.438 \\
\hline Pann $\left(\mathrm{mm} \mathrm{yr}^{-1}\right)$ & 0.3695 & 191.0206 & 0.5815 & 197.11 \\
\hline
\end{tabular}

northern Sicily (Frisia et al., 2006), shows lower oxygen and carbon isotope values than in the early Holocene and a small peak centered at ca. $3100 \mathrm{yr}$ BP. The stalagmite stopped to grow after $2800 \mathrm{cal}$ BP, suggesting enhanced dryness. An increase of Olea pollen soon before $3000 \mathrm{cal} \mathrm{BP}$ is found in Adriatic cores and in Italian continental ones (CombourieuNebout et al., 2013; Di Rita and Magri, 2009; Mercuri et al., 2012, 2013), indicating that this was a rather general change in the Mediterranean landscape. The exploitation of olives in Greece during the Bronze Age has been documented by both macroremains and pollen (Kouli, 2012). Presence of olive stones is documented at the early Iron Age archaeological site of Selinunte, southwestern Sicily (Stika et al., 2008), some centuries later than the pollen spread of Pergusa. No evidence of this step was found at Gorgo Basso (Tinner et al., 2009), inside the natural area of distribution of Olea europea, but we have to consider that Lago di Pergusa lies in a privileged position to observe past land use, in a zone widely and strongly exploited and contended between 3200 and $2700 \mathrm{yr}$ BP, before the Greek dominance (Giannitrapani and Pluciennik, 1998). Herbaceous taxa found nowadays in the lacustrine vegetation belts in the case of water decrease, were quite important in the last three millennia.

At Lago di Pergusa the deterioration of climate conditions accompanies the evolution of human activities that become stronger over the last 2.5 millennia, in a period in which Siracusans, Greeks, Sicels, Carthaginians and Romans contended the perched town of Enna and its territory. Pollen indicators of cultures (Secale, Linum, Vitis) are found as a continuous signal over the last millennia. Sicily and the region of Enna were known, after the conquering of the island by Romans, as the granary of the empire. The continuous curves of cereals and accompanying weed taxa recorded since ca. $3000 \mathrm{yr}$ BP, suggest that this land use had already started during the domain of Sicanians and increased under the Greeks. Worthy of mention is the expansion of Secale, supporting that of Cerealia tp., at the end of the Roman empire, when Byzantines ruled the area. This crop is known to be more resistant and less demanding than wheat. Local Olea cultivation is undisputed only in the last few centuries, after 1600 AD.

\subsection{Climate reconstruction}

Table 3 shows that the reliability of both methods is good, in particular for the reconstruction of summer precipitation and winter temperature. Quantitative climate reconstructions for PG2 were performed for annual temperature and precipitation, and summer/winter temperature and precipitation (Fig. 7). Values of the seasonal temperature and precipitation parameters are expressed as anomalies and thus can be compared with the results obtained from PG1 core (Peyron et al., 2013) and with the reconstruction of temperatures of the warmest/coldest month for southwestern Europe (Davis et al., 2003). It is clear that although similarities exist, there are distinct differences between methods. The most important difference between methods occurs over the last $3000 \mathrm{yr}$ (Fig. 7) with more marked changes using the MAT. These strong oscillations can be due to human impact and to the fact that MAT is more sensitive than WAPLS, particularly when the variability of modern pollen spectra is highly due to human impact. For the last $3000 \mathrm{yr}$, the amplitude of the changes reconstructed with the MAT needs to be interpreted with caution. However, if high criticism was often addressed to the reliability of modern pollen data for the reconstruction of climate, given that human impacts may influence these modern pollen samples, our pollen-based climate 
reconstructions appear to show solid results and a consistent trend through time.

Despite differences in the reconstruction of the amplitude of changes, both methods underline a clear climate trend towards aridification and warming over the last 3 millennia. This trend was interrupted by several phases characterized by cooling and moisture. A first cooling phase is reconstructed between 2600 and $2000 \mathrm{cal} \mathrm{BP}$, which corresponds to a maximum of precipitation. Other phases of cooling and moisture are found at 1650-1100, 850-550, 400-200 cal BP.

Enough precipitation should have been available in the ancient Greek site of Morgantina, nearby Pergusa, as a public fountain was fed only by rainy water in the 4 th $\mathrm{c}$. BC (M. Bell, personal communication, 2012). It is interesting to note what happened in other Mediterranean sites: the lake level at lake Malik (Albania) is medium/high between 2600 and $2000 \mathrm{cal} \mathrm{BP}$ (Fouache et al., 2010) and at lake Accesa (central Italy) between ca. 2800 and 2000 cal BP (Magny et al., 2007). Most importantly this period roughly coincides with the highest phase of the lake level and the amount of precipitation (2500-2140 cal BP) in southern Spain as reconstructed in Zoñar Lake (Martín-Puertas et al., 2009). Stable isotope records from lake Shkodra (Albania) show the wettest period of the last $4500 \mathrm{cal} \mathrm{BP}$ at ca. 2500-2000 cal BP (Zanchetta et al., 2012b). The first two phases of cooling (2600-2000, 1650-1100 cal BP) chronologically comprehend the last two periods of the Calderone glacier expansion (Giraudi et al., 2011). A general correlation is found with climate trends reconstructed in Morocco (Cheddadi et al., 1998) and with the phases of more important erosional activity in Tunisia (Marquer et al., 2008), which seems well correlated with phases of precipitation increase that we reconstruct in Sicily.

These independent arguments support the hypothesis that landscape changes recorded at Pergusa over the recent past were mainly related to climate stress than to human impact on vegetation, even if the last is uncontested.

\section{Conclusions}

In order to assess the degree of human-environment interactions there is the urgent and unavoidable need to carry out scientific investigations on natural archives linked to human history like Lago di Pergusa. Lago di Pergusa turned out to be a privileged observatory for climate changes and human activity, even if the two signals cannot be easily distinguished only by pollen. This is not a negative issue at all, but a positive one. Failure to consider the complex interactions between humans and their environment could have lead either to an environmentally deterministic view of socio-cultural change or to a complete neglect of possible environmental impact on human action and history.

Our data show that the first phase of opening of forests recorded in the core lasted for more than two millennia, from ca. 5400 to ca. $3200 \mathrm{cal} \mathrm{BP}$, a period characterized by frequent though slight vegetation changes. A strong change of the environment occurred around $3200 \mathrm{cal} \mathrm{BP}$, when an expansion of Olea is found. After $2700 \mathrm{cal}$ BP human impact is uncontested and overlapped a natural change. We were in fact able to get two different, mixed and hard to disentangle, clues from pollen, signalling both a climatic and a human impact.

A solution to overcome this impasse was to use presentday lacustrine vegetation studies, climate reconstructions from pollen using different methods and other proxies from the same site and from nearby sites. Preliminary data from isotope analyses of the sediments (Zanchetta et al., 2013) show several anomalies between $\delta^{18} \mathrm{O}$ and $\delta^{13} \mathrm{C}$ curves and the vegetation changes, probably to correlate with periods of intense land exploitation.

The important fluctuations of vegetation around Lago di Pergusa seem to be mostly dependent from climate variations even over the recent past, but cannot be regarded as totally independent from human activities.

Our climate reconstruction is inevitably influenced by human-induced changes of the landscape and the amplitude of the reconstructed changes might be overestimated in our work. However, our results are consistent with former works from various sites all around the Mediterranean basin, which were based on independent proxies.

Our data underlines a synergy between human activities and climate in shaping the landscape in Sicily in the recent past. We also propose that climate had an effect on human activities, which could have been oriented towards the culture of olive trees in the Sicilian inlands, during a period of climate conditions favourable to its spread.

Climate reconstruction points out four phases of cooling and enhanced wetness in the last three millennia (2600-2000, 1650-1100, 850-550, 400-200 cal BP). They are consistent with other climate proxies from the Mediterranean area, once more indicating that a close relation existed between climate and human history.

Acknowledgements. This work was funded by the French CNRS through the ANR Program "LAMA". The authors are in debt with Rosa Termine, Università degli Studi di Enna "Kore", for her help in the logistic during the drilling campaign. The coring operations have been authorized by Ente Gestore della Riserva of Provincia Regionale di Enna. The help of four anonymous referees is acknowledged.

Edited by: N. Combourieu Nebout 


\section{References}

Andersen, S. T.: Identification of wild grass and cereal pollen, Danmarks Geologiske Undersogelse Årbog 1978, 69-92, 1978.

Bernabò Brea, L.: La Sicilia prima dei Greci. Milano, Il Saggiatore, 1st Edn., 1961.

Blaauw, M.: Methods and code for "classical" age-modelling of radiocarbon sequences, Quat. Geochronol., 5, 512-518, 2010.

Brullo, S., Minissale, P., and Spampinato, G.: Considerazioni fitogeografiche sulla flora della Sicilia, Ecologia Mediterranea, 21, 99-107, 1995.

Brullo, S., Scelsi, F., Siracusa, G., and Spampinato, G.: Caratteristiche bioclimatiche della Sicilia, Giornale Botanico Italiano, 130, 177-185, 1996.

Calvo, S., Marceno, C., Ottonello, D., Frada Orestano, C., Romano, S., and Longo, A.: Osservazioni naturalistiche ed ecologiche intorno al lago Pergusa, Naturalista siciliano S.IV, 19, 63-84, 1995.

Caron, B., Sulpizio, R., Zanchetta, G., Siani, G., and Santacroce, R.: The Late Holocene to Pleistocene tephrostratigraphic record of lake Orhid (Albania), C. R. Geosci., 342, 453-466, 2010.

Carrión, J. S., Fernández, S., González-Sampériz, P., Gil-Romera, G., Badal, E., Carrión-Marco, Y., López-Merino, L., López-Sáez, J. A., Fierro, E., and Burjachs, F.: Expected trends and surprises in the Lateglacial and Holocene vegetation history of the Iberian Peninsula and Balearic Islands, Review of Paleobotany and Palynology, 162, 458-475, 2010a.

Carrión, J. S., Fernández, S., Jiménez-Moreno, Fauquette, S., GilRomera, G., González-Sampériz, P., and Finlayson, C.: The historical origins of aridity and vegetation degradation in southeastern Spain, J. Arid Environ., 74, 731-736, 2010b.

Cheddadi, R., Lamb, H. F., Guiot, J., and van der Kaars, S.: Holocene climatic change in Morocco: a quantitative reconstruction from pollen data, Clim. Dynam., 14, 883-890, 1998.

Cioni, R., Marianelli, P., and Santacroce, R.: Thermal and compositional evolution of the shallow magma chambers of Vesuvius: evidence from pyroxene phenocrysts and melt inclusions, J. Geophys. Res., 103, 18277-18294, 1997.

Coltelli, M., Del Carlo, P., and Vezzoli, L.: Stratigraphic constraints for explosive activity in the past $100 \mathrm{ka}$ at Etna Volcano, Italy, Int. J. Earth Sci., 89, 665-677, 2000.

Combourieu-Nebout, N., Peyron, O., Bout-Roumazeilles, V., Goring, S., Dormoy, I., Joannin, S., Sadori, L., Siani, G., and Magny, M.: Holocene vegetation and climate changes in central Mediterranean inferred from a high-resolution marine pollen record (Adriatic Sea), Clim. Past Discuss., 9, 1969-2014, doi:10.5194/cpd-9-1969-2013, 2013.

Cour, P.: Nouvelles techniques de détection des flux et des retombées pollinique: étude de la sédimentation des pollens et des spores à la surface du sol, Pollen et Spores, 16, 103-141, 1974.

Cremaschi, M., Pizzi, C., and Valsecchi, V.: Water management and land use in the terramare and a possible climatic co-factor in their abandonment: The case study of the terramara of Poviglio Santa Rosa (northern Italy), Quaternary Int., 151, 87-98, 2006.

Davis, B. A. S., Brewer, S., Stevenson, A. C., and Guiot, J.: The temperature of Europe during the Holocene reconstructed from pollen data, Quaternary Sci. Rev., 22, 1701-1716, 2003.

de Beaulieu, J. L., Miras, Y., Andrieu-Ponel, V., and Guiter, F.: Vegetation dynamics in north-western Mediterranean regions: Instability of the Mediterranean bioclimate, Plant Biosyst., 139, 114126, 2005.
Desprat, S., Combourieu-Nebout, N., Essallami, L., Sicre, M. A., Dormoy, I., Peyron, O., Siani, G., Bout Roumazeilles, V., and Turon, J. L.: Deglacial and Holocene vegetation and climatic changes in the southern Central Mediterranean from a direct land-sea correlation, Clim. Past, 9, 767-787, doi:10.5194/cp-9767-2013, 2013.

Di Pasquale, G., Garfi, G., and Quezel, P.: Sur Ia presence d'un Zelkova nouveau en Sicile sud-orientale (Ulmaceae), Biocosme Mésogéen Nice, 8-9, 401-409, 1992.

Di Rita, F. and Magri, D.: Holocene drought, deforestation and evergreen vegetation development in the central Mediterranean: A 5500 year record from Lago Alimini Piccolo, Apulia, southeast Italy, Holocene, 19, 295-306, 2009.

Dormoy, I., Peyron, O., Combourieu Nebout, N., Goring, S., Kotthoff, U., Magny, M., and Pross, J.: Terrestrial climate variability and seasonality changes in the Mediterranean region between 15000 and 4000 years BP deduced from marine pollen records, Clim. Past, 5, 615-632, doi:10.5194/cp-5-615-2009, 2009.

Duro, A., Piccione, V., Scalia, C., and Zampino, D.: Fitoclima della Sicilia. Contributo alla caratterizzazione del fattore aridità Atti del $5^{\circ}$ Workshop "Progetto Strategico Clima Ambiente e Territorio nel Mezzogiorno", 2, 133-50, 1997.

Finsinger, W., Heiri, O., Valsecchi, V., Tinner, W., and Lotter, A. F.: Modern pollen assemblages as climate indicators in southern Europe, Global Ecol. Biogeogr., 16, 567-582, 2007.

Finsinger, W., Colombaroli, D., De Beaulieu, J.-L., Valsecchi, V., Vannière, B., Vescovi, E., Chapron, E., Lotter, A. F., Magny, M., and Tinner, W.: Early to mid-Holocene climate change at Lago dell'Accesa (central Italy): climate signal or anthropogenic bias?, J. Quat. Sci., 25, 1239-1247, 2010.

Frisia, S., Borsato, A., Mangini, A., Spötl, Ch., Madonia, G., and Sauro, U.: Holocene climate variability in Sicily from a discontinuous stalagmite record and the Mesolithic to Neolithic transition, Quaternary Res., 66, 388-400, 2006.

Fouache, E., Desruelles S., Magny, M., Bordon, A., Oberweiler, C., Coussot, C., Touchais, G., Ler, P., Lézine, A.-M., Fading, L., and Roger, R.: Palaeogeographical reconstructions of Lake Maliq (Korça Basin, Albania) between 14000 BP and 2000 BP, J. Archaeol. Sci., 37, 525-535, 2010.

Giannitrapani, E.: Aspetti culturali e dinamiche del popolamento di età preistorica della provincia di Enna. Quaderni della Soprintendenza BB.CC.AA. di Enna 1, 1-37, 2012a.

Giannitrapani, E.: Dalla capanna alla casa. Architettura domestica, Mito e archeologia degli Erei. Museo Diffuso Ennese. Itinerari archeologici, Soprintendenza BB.CC.AA. di Enna, 4753, 2012b.

Giannitrapani, E. and Pluciennik, M.: La seconda campagna di ricognizione (settembre 1997) del progetto "Archeologia nella Valle del Torcicoda", Sicilia Archeologica, 96, 59-69, 1998.

Giorgi, F. and Lionello, P.: Climate change projections for the Mediterranean region, Global Planet. Change, 63, 90-104, 2008.

Giraudi, C., Magny, M., Zanchetta, G., and Drysdale, R. N.: The Holocene climate evolu- tion of the Mediterranean Italy: a review of the continental geological data, Holocene, 21, 105-115, 2011.

Goeury, C. and de Beaulieu, J.-L.: A propos de la concentration du pollen à l'aide de la liqueur de Thoulet dans les sédiments minéraux, Pollen et Spores, 21, 239-251, 1979.

Guiot, J.: Methodology of the last climatic cycle reconstruction in France from pollen data, Palaeogeogr. Palaeocl., 80, 49-69, 
1990.

Gunn, D. E. and Best, A. I.: A new automated non-destructive system for high resolution multi-sensor core logging of open sediment cores, Geo-Mar. Lett., 18, 70-77, 1998.

IPCC: Climate change 2007: The Physical Science Basis, Contribution of Working Group I to the Fourth Assessment, 2007.

Juggins, S.: $C^{2}$ User guide. Software for ecological and palaeoecological data analysis and visualisation, University of Newcastle, Newcastle upon Tyne, UK, 69 pp., 2003.

Kouli, K.: Vegetation development and human activities in Attiki (SE Greece) during the last 5,000 years, Veg. Hist. Archaeobot., 21, 267-278, 2012.

Le Bas, M. J., Le Maitre, R. W., Streckheisen, A., and Zanettin, B.: Chemical classification of volcanic rocks based on the total alkali-silica diagram, J. Petrol., 27, 745-750, 1986.

Magny, M., Vannière, B., de Beaulieu, J.-L., Bégeot, C., Heiri, O., Millet, O., Bossuet, G., Peyron, O., Brugiapaglia, E., and Leroux, A.: Holocene climate changes in the central Mediterranean as recorded by lake-level fluctuations at Lake Accesa (Tuscany, Italy), Quaternary Sci. Rev., 26, 1951-1964, 2007.

Magny, M., Vannière, B., Zanchetta, G., Fouache, E., Touchais, G., Petrika, L., Coussot, C., Walter-Simonnet, A.-V., and Arnaud, F.: Possible complexity of the climatic event around 4300-3800 cal. BP in the central and western Mediterranean, Holocene, 19, 823833, 2009.

Magny, M., Vannière, B., Calò, C., Millet, L., Leroux, A., Peyron, O., Zanchetta, G., La Mantia, T., and Tinner, W.: Holocene hydrological changes in south-western Mediterranean as recorded by lake-level fluctuations at Lago Preola, a coastal lake in southern Sicily, Italy, Quaternary Sci. Rev., 30, 2459-2475, 2011.

Magny, M., Peyron, O., Sadori, L., Ortu, E., Zanchetta, G., Vannière, B., and Tinner, W.: Contrasting patterns of precipitation seasonality during the Holocene in the south- and northcentral Mediterranean, J. Quat. Sci., 27, 290-296, 2012.

Magny, M., Combourieu Nebout, N., de Beaulieu, J. L., BoutRoumazeilles, V., Colombaroli, D., Desprat, S., Francke, A., Joannin, S., Peyron, O., Revel, M., Sadori, L., Siani, G., Sicre, M. A., Samartin, S., Simonneau, A., Tinner, W., Vannière, B., Wagner, B., Zanchetta, G., Anselmetti, F., Brugiapaglia, E., Chapron, E., Debret, M., Desmet, M., Didier, J., Essallami, L., Galop, D., Gilli, A., Haas, J. N., Kallel, N., Millet, L., Stock, A., Turon, J. L., and Wirth, S.: North-south palaeohydrological contrasts in the central Mediterranean during the Holocene: tentative synthesis and working hypotheses, Clim. Past Discuss., 9, 1901-1967, doi:10.5194/cpd-9-1901-2013, 2013.

Marianelli, P. and Sbrana, A.: Risultati di misure di standard di minerali e di vetri naturali in microanalisi a dispersione di energia, Atti Società Toscana di Scienze Naturali Memorie, 105, 57-63, 1998.

Marquer, L., Pomel, S., Abichou, A., Schulz, E., Kaniewski, D., and Van Campo, E.: Late Holocene high resolution palaeoclimatic reconstruction inferred from Sebkha Mhabeul, southeast Tunisia, Quaternary Res., 70, 240-250, 2008.

Martín-Puertas, C., Valero-Garcés, B. L., Brauer, A., Mata, M. P., Delgado-Huertas, A., and Dulski, P.: The Iberian-Roman Humid Period (2600-1600 cal yr BP) in the Zoñar Lake varve record (Andalucía, southern Spain), Quaternary Res., 71, 108120, 2009.
Mercuri, A. M., Accorsi, C. A., Bandini Mazzanti, M., Bosi, G., Cardarelli, A., Labate, D., Marchesini, M., and Trevisan Grandi, G.: Economy and environment of Bronze Age settlements - Terramare - in the Po Plain (Northern Italy): first results of the archaeobotanical research at the Terramara di Montale, Veg. Hist. Archaeobot., 16, 3-60, 2006.

Mercuri, A. M., Sadori, L., and Blasi, C.: Archaeobotany for cultural landscape and human impact reconstructions, Plant Biosyst., 144, 860-864, 2010.

Mercuri, A. M., Sadori, L., and Uzquiano Ollero, P.: Mediterranean and north-African cultural adaptations to mid-Holocene environmental and climatic change, Holocene, 21, 189-206, 2011.

Mercuri, A. M., Bandini Mazzanti, M., Torri, P., Vigliotti, L., Bosi, G., Florenzano, A., Olmi, L., and Massamba N'siala, I.: marine/terrestrial integration for mid-late Holocene vegetation history and the development of the cultural landscape in the Po Valley as a result of human impact and climate change, Veg. Hist. Archaeobot., 21, 353-372, 2012.

Mercuri, A. M., Bandini Mazzanti, M., Florenzano, A., Montecchi, M. C., and Rattighieri, E.: Olea, Juglans and Castanea: the OJC group as pollen evidence of the development of human-induced environments in the Italian peninsula, Quaternary Int., 303, 24 42, 2013

Noti, R., van Leeuwen, J., Colombaroli, D., Vescovi, E., Pasta, S., La Mantia, T., and Tinner, W.: Mid- and late-Holocene vegetation and fire history at Biviere di Gela, a coastal lake in southern Sicily, Italy, Veg. Hist. Archaeobot., 18, 371-387, 2009.

Pérez-Obiol, R. and Sadori, L.: Similarities and dissimilarities, synchronisms and diachronisms in the Holocene vegetation history of the Balearic Islands and Sicily, Veg. Hist. Archaeobot., 16, 259-265, 2007.

Peyron, O., Goring, S., Dormoy, I., Kotthoff, U., Pross, J., de Beaulieu, J.-L., Drescher-Schneider, R., Vannière, B., and Magny, M.: Holocene seasonality changes in the central Mediterranean region reconstructed from the pollen sequences of Lake Accesa (Italy) and Tenaghi Philippon (Greece), Holocene, 21, 131-146, 2011.

Peyron, O., Magny, M., Goring, S., Joannin, S., de Beaulieu, J.L., Brugiapaglia, E., Sadori, L., Garfi, G., Kouli, K., Ioakim, C., and Combourieu-Nebout, N.: Contrasting patterns of climatic changes during the Holocene across the Italian Peninsula reconstructed from pollen data, Clim. Past, 9, 1233-1252, doi:10.5194/cp-9-1233-2013, 2013.

Pignatti, S.: Flora d'Italia (three volumes), EDAGRICOLE, Bologna, 1982.

Pignatti, S.: Ecologia del Paesaggio, UTET, Torino, 1994.

Pignatti, S. and Nimis, P. L.: Biomi, in: Ecologia Vegetale, edited by: Pignatti, S., UTET, Torino, 319-355, 1995.

Pross, J., Kotthoff, U., Müller, U. C., Peyron, O., Dormoy, I., Schmiedl, G., Kalaitzidis, S., and Smith, A. M.: Massive perturbation in terrestrial ecosystems of the Eastern Mediterranean region associated with the $8.2 \mathrm{kyr}$ climatic event, Geology, 37, 887-890, 2009.

Quezel, P., Di Pasquale, G., and Garfi, G.: Découverte d'un Zelkova en Sicile sud-orientale, Incidences biogéographiques et historiques, Comptes Rendus Hebdomadaires des Séances de l'Academie des Sciences de Paris, 316, 21-26, 1993.

Reille, M.: Pollen et spores d'Europe et d'Afrique du Nord, Laboratoire de Botanique Historique et Palynologie, Université d'Aix- 
Marseille III, 1992.

Reille, M.: Pollen et spores d'Europe et d'Afrique du Nord Supplément 1, Laboratoire de Botanique Historique et Palynologie, Université d'Aix-Marseille III, 1995.

Reille, M.: Pollen et spores d'Europe et d'Afrique du Nord Supplément 2, Laboratoire de Botanique Historique et Palynologie, Université d'Aix-Marseille III, 1998.

Reimer, P. J., Baillie, M. G. L., Bard, E., Bayliss, A., Beck, J. W., Blackwell, P. G., Bronk Ramsey, C., Buck, C. E., Burr, G. S., Edwards, R. L., Friedrich, M., Grootes, P. M., Guilderson, T. P., Hajdas, I., Heaton, T. J., Hogg, A. G., Hughen, K. A., Kaiser, K. F., Kromer, B., McCormac, F. G., Manning, S. W., Reimer, R. W., Richards, D. A., Southon, J. R., Talamo, S., Turney, C. S. M., van der Plicht, J., and Weyhenmeyer, C. E.: IntCal09 and Marine09 radiocarbon age calibration curves, $0-50,000$ years cal BP, Radiocarbon, 51, 1111-1150, 2009.

Roberts, N., Brayshaw, D., Kuzucuoğlu, C., Pérez, R., and Sadori, L.: The mid-Holocene climatic transition in the Mediterranean: Causes and consequences, Holocene, 21, 3-13, 2011.

Sadori, L.: Postglacial Pollen Records of Southern Europe, in: Encyclopedia of Quaternary Science, edited by: Elias, S. A., Vol. 4, 179-188, Elsevier, Amsterdam, 2013.

Sadori, L. and Giardini, M.: Charcoal analysis, a method to study vegetation and climate of the Holocene: The case of Lago di Pergusa, Sicily (Italy), Geobios, 40, 173-180, 2007.

Sadori, L. and Giardini, M.: Environmental history in the Mediterranean basin: microcharcoal as a tool to disentangle human impact and climate change, in: Charcoals from the Past: Cultural and Palaeoenvironmental Implications, edited by: Fiorentino, G. and Magri, D., BAR International Series, 1807, 229-236, 2008.

Sadori, L. and Narcisi, B.: The Postglacial record of environmental history from Lago di Pergusa, Sicily, Holocene, 11, 655-671, 2001.

Sadori, L., Giraudi, C., Petitti, P., and Ramrath, A.: Human impact at Lago di Mezzano (central Italy) during the Bronze Age: A multidisciplinary approach, Quaternary Int., 113, 5-17, 2004.

Sadori, L., Zanchetta, G., and Giardini, M.: Last Glacial to Holocene palaeoenvironmental evolution at Lago di Pergusa (Sicily, Southern Italy) as inferred by pollen, microcharcoal, and stable isotopes, Quaternary Int., 181, 4-14, 2008.

Sadori, L., Giardini, M., Giraudi, C., and Mazzini, I.: The plant landscape of the imperial harbour of Rome, J. Archaeol. Sci., 37, 3294-3305, 2010a.

Sadori, L., Mercuri, A. M., and Mariotti Lippi, M.: Reconstructing past cultural landscape and human impact using pollen and plant macroremains, Plant Biosyst., 144, 940-951, 2010 b.

Sadori, L., Jahns, S., and Peyron, O.: Mid-Holocene vegetation history of the central Mediterranean, Holocene, 21, 117-129, 2011.

Stika, H.-P., Heiss, A., and Zach, B.: Plant remains from the early Iron Age in western Sicily: differences in subsistence strategies of Greek and Elymian sites, Veg. Hist. Archaeobot., 17, 139-148, 2008.
Sulpizio, R., Van Welden, A., Caron, B., and Zanchetta, G.: The Holocene tephrostratigraphic record of Lake Shkodra (Albania and Montenegro), J. Quat. Sci., 25, 633-650, 2010.

ter Braak, C. J. F. and Juggins, S.: Weighted averaging partial least squares regression (WA-PLS): an improved method for reconstructing environmental variables from species assemblages, Hydrobiologia, 269/270, 485-502, 1993.

Tinner, W., van Leeuwen, J. F. N., Colombaroli, D., Vescovi, E., van der Knaap, W. O., Henne, P. D., Pasta, S., D’Angelo, S., and La Mantia, T.: Holocene environmental and climatic changes at Gorgo Basso, a coastal lake in southern Sicily, Italy, Quaternary Sci. Rev., 28, 15-16, 2009.

Tusa, S.: La Sicilia e la preistoria, Palermo, Sellerio, 2nd Edn., 1992.

Vannière, B., Bossuet, G., Walter-Simonnet, A.-V., Ruffaldi, P., Adatte, T., Rossy, M., and Magny, M.: High resolution record of environnemental changes and tephrochronological markers of the Last Glacial-Holocene Transition at Lake Lautrey (Jura, France), J. Quat. Sci., 18, 797-808, 2004.

Vogel, H., Zanchetta, G., Sulpizio, R., Wagner, B., and Nowaczyk, N.: A tephrostratigraphic record for the last glacial-interglacial cycle from Lake Ohrid, Albania and Macedonia, J. Quat. Sci., 25, 320-338, 2009.

Wagner, B., Sulpizio, R., Zanchetta, G., Wulf, S., Wessels, M., Daut, G., and Nowaczyk, N.: The last 40 ka tephrostratigraphic record of Lake Ohrid, Albania and Macedonia: a very distal archive for ash dispersal from Italian volcanoes, J. Volcanol. Geoth. Res., 1, 71-80, 2008.

Zampino, D., Duro, A., Piccione, V., and Scala, C.: Fitoclima della Sicilia - Termoidrogrammi secondo Walter e Lieth, Atti del $5^{\circ}$ Workshop "Progetto Strategico Clima Ambiente e Territorio nel Mezzogiorno", 2, 7-121, 1997.

Zanchetta, G., Borghini, A., Fallick, A. E., Bonadonna, F. P., and Leone, G.: Late Quaternary palaeohydrology of Lake Pergusa (Sicily, southern Italy) as inferred by stable isotopes of lacustrine carbonates, J. Paleolimnol., 38, 227-239, 2007.

Zanchetta, G., Giraudi, C., Sulpizio, R., Magny, M., Drysdale, R. N., and Sadori, L.: Constraining the onset of the Holocene "Neoglacial" over the central Italy using tephra layers, Quaternary Res., 78, 236-247, 2012a.

Zanchetta, G., Van Welden, A., Baneschi, I., Drysdale, R., Sadori, L., Roberts, N., Giardini, M., Beck, C., Pascucci, V., and Sulpizio R.: Multiproxy record for the last 4500 years from Lake Shkodra (Albania/Montenegro), J. Quat. Sci., 27, 780-789, 2012b.

Zanchetta, G., Baneschi, I., Ortu, E., Sadori, L., Peyron, O., Desmet, M., Termine, R., Vannière, B., and Magny, M.: Holocene climatic and environmental changes in central mediterranean: stable isotopes and geochemistry of bulk carbonate and organic matter from Lago di Pergusa (Sicily), in preparation, 2013. 